\title{
REDUCING TIME LOSSES IN OPERATIONAL ACTIONS OF A FOOD PRODUCTION LINES
}

\author{
Jukka Lintilä ${ }^{1}$, Josu Takala ${ }^{2}$ \\ 1 Valio ltd, Finland \\ ${ }^{2}$ University of Vaasa, Faculty of Technology, Production, Finland \\ Corresponding author: \\ Jukka Lintilä \\ Valio Ltd, Finland \\ Osmankatu 2, 60320 Seinäjoki, Finland \\ phone: +358503840886 \\ e-mail: jukka.lintila@valio.fi
}

Received: 7 March 2013

Accepted: 29 April 2013

\begin{abstract}
Most of the companies are interested in developing their production processes. With production process development, companies can meet their customers demands better. Tight competition is one reason that forces companies to use their production equipment as efficiently as they can. Improved production processes result in cost savings, flexibility, and in opportunities to plan companies activities more efficiently. The purpose of this research is to examine and cut operational times in food production processes. Two production lines were chosen for closer examination: spread/butter production line and quark production line. The main focus was to prevent operational time losses in these production lines. Research is divided into two separate sections: theoretical and empirical part. Theoretical part formulates guidelines and theoretical basis which is then employed in the empirical part. The theoretical part discusses Lean management philosophy, OEE indicator, SMED and questionnaire research method that comes from the sense and respond theory. In the empirical section, SMED and questionnaire method are used to examine operational activities. The focus is in finding critical characteristics from the production line's starting-, product change-, and closing-setups. Result was that certain characteristics can be found to be critical factors. Those characteristics are connected to operational time losses. Another result is, that SMED and questionnaire research method are an effective way to examine issues with production. Both methods produced similar results in finding development targets from the production line, hence the simultaneous use of both is beneficial, as additional confirmation for the first methods findings can be obtained by securing the result with the other one.
\end{abstract}

KEYWORDS

process development, operational times, sense and respond, SMED, OEE.

\section{Introduction}

Process development is very crucial part of the companies focus areas. Making more products with same resources is a goal that many companies are aiming at. Never ending process development is ensuring that company is maintaining its competitiveness in the markets. It also makes easier to gain new customers, which benefits company and its owners. When we are researching production processes, we can find important parts and attributes that can lead to significant results. Making these parts more efficient would affect to the whole production process positively. Companies that are operating in industri- al markets are usually making their own products. Production plants are forming from many complicated processes. They are always transforming raw materials into some kind of products. Whole production can be divided into production lines that are responsible for transforming process. Production lines are using factors of production to make end products. Key point is that these processes should run as smooth as possible.

Transformation process should be as quick as it can get. This way money is tied to the production as little as possible. Ruling these processes efficiently should form basic ground to the business success. 
This research was conducted in a food company called Valio Ltd. Valio ltd is a Finnish food company that is owned by Finnish dairy farmers. Research problem is very interesting: How can we decrease operational times so that we could achieve as much as possible productive production time? Research was focused on two different production lines. First line is making spread/butter type products and the other one is making quark products. Production lines are containing products making process, packing process, packing products to wholesale packages, and forming whole product pallets. Research was focused to these specific parts of the lines. Process parts that were handling/producing raw-materials and storage of end products were ruled out.

\section{Literature Review}

\section{Single Minute Exchange of Die (SMED)}

Customers are demanding fast delivery and reliable delivering schedule. For meeting these requirements, companies are forced to organize their production in a way that product passing times should be as fast as it can get. Another option could be stocking products, but then money would be bound to the stocks. Lean management has drive companies to cut down all necessities. Production flexibility can be seen in product batches. Companies should focus to small batches because then they can react to customer demands better and drive their production to make to order system. Smaller batches are leading to more changeovers in production. That is a reason for companies to improve their actions in batch changeovers [1].

SMED was created to improve setup changes and to cut production time losses. SMED is known for being powerful lean management method. It was originally created in Toyota motor company production plant, by consultant named Shigeo Shingo. The goal was that every changeover could be done less the 10 minutes, hence the name SMED (Single minute exchange of die) [2]. We must remember that the ultimate goal would be changeover that will give result as a zero. Time loss would be zero minutes. These kinds of changes are named One Touch Setups, push one button and the setup is done [3]. SMED can be applied easily to many different kind of production lines. Ideas, that this method brings, are very easy to adapt to any kind of setups. Many of them are concerning human behavior and a way how people are handling changeovers. Usually there are no investments required, at least in the beginning of improvement process.

\section{Three steps model}

SMED method is implemented with three different steps [2, 3]. All these steps are very easily to follow, but it requires patience, because examined information must be gathered very precisely. Steps:

1. Dividing setup works to internal and external setups. First step is to follow the whole setup from start to end. Every operation and movement should be written down, measure how long it will last and it should be divided to internal or external operation. Internal operation is something that is done when the production machine is shut down. External operation is done when the machine is still operating. For example new materials are fetched near to machine, while it is still operating old materials. At the same time information can be analyzed so that the preliminary decisions can be made which internal operations could be transformed into external operations. Same setup should be monitored many times and with different people doing setups. This way SMED can reveal best practices to manage the changeovers.

2. Internal operations are transformed to external operations. In this stage all the possible internal operations should be transformed into external operations.

3. Make changeover as lean as it can get. Improve all remaining internal operations. Operations should be done parallel way and automatic adjustments, models, templates, and special tools should be used as much as possible. Unnecessary movements and wrong work habits should be root out in this stage.

Target is to create standard for proper changeover that every operator would use. Approximately SMED can reduce time in changeover 80-95\% from the original time [4].

\section{Overall Equipment Effectiveness (OEE)}

OEE is key measurement indicator in Lean production. It indicates how efficiently production is producing a product that meets the quality requirements [5]. OEE is counting production lines efficiency by three different sectors. These sectors are:

- Availability $\%$.

- Speed \%.

- Quality \%.

OEE is revealing the state of the production. For example if production line is available $80 \%$ of time, it operates at $80 \%$ of speed and the quality rate is $80 \%$ then the OEE Number is only $51 \%$. 


\section{Sense and respond}

Sense and respond - methodology has been invented by Stephan H. Haeckel. Method is offering tools to handle futures uncertainties. Sense and respond - organization is trying to sense customer needs and business opportunities when they occur. It's not focused to reveal future incomes. Reacting to signals as fast and correctly as possible, before they are weakened or changed, is a top priority [6].

Fast development of information technology has affected many companies to change their make to sell system to sense and respond system. Make and sell systems are losing it's battle to sense and respond systems because system that is based on a budget and history knowledge isn't match for quick and adaptive system like sense and respond. Best case scenario is that system can predict customer expectations that haven't even occurred yet. Final solution to operation system is an outcome that can find critical resources to satisfied customer demand. And execution is efficient 7].

Sense and respond -model has been target to active development past years. Based on this original theory Rautiainen and Takala [8] have developed questionnaire method that can reveal customer satisfaction and point out critical resources or attributes from the system. This method can be implemented to internal and external organizational attributes. It is considering attributes development in past and it is predicting the attributes future development. Original idea for this questionnaire is to develop a quick and reliable way to find out customer needs and to react to these needs so that the right attributes are developing. It is also easy and quick way to gather information.

\section{Questionnaire}

Questionnaire is formed from attributes that are relevant and crucial to research. Each attribute must be very close to research problem. Questionnaire was formed same way as it is in Fig. 1. Original questionnaire was modified because it contained part that was asking respondent opinion about competitors processes. We can assume that process workers aren't familiar with competitors processes. Respondents are

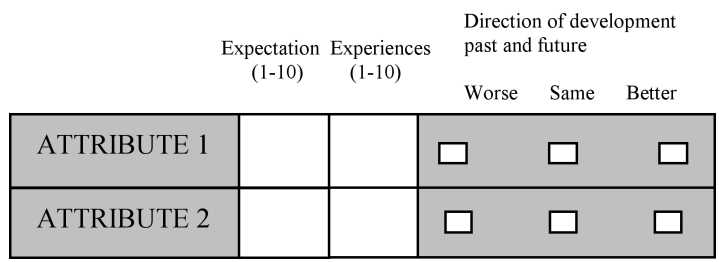

Fig. 1. Model of the questionnaire [8] (modified). assessing attributes by expectations and experiences with numbers. Direction of development, past and future, is assessed by choice of worse, same, or better. Questionnaire has an open space that respondent can write more information, if needed. Table 1 is indicating what kind of attributes was used in this research.

Table 1

Questionnary attributes.

\begin{tabular}{l|l}
\hline \multicolumn{1}{l}{ Start setup } & \multicolumn{1}{l}{ Availability of materials/raw materials } \\
\hline Attribute 1 & Proper tools \\
\hline Attribute 2 & Quality issues \\
\hline Attribute 3 & Work help \\
\hline Attribute 4 & Other teams waiting \\
\hline Attribute 5 & Information flow \\
\hline Attribute 6 & Changeover setup \\
\hline Attribute 7 & Availability of materials/raw materials \\
\hline Attribute 8 & Proper tools \\
\hline Attribute 9 & Production schedule \\
\hline Attribute 10 & Quality issues after changeover \\
\hline Attribute 11 & Waiting for the previous process \\
\hline Attribute 12 & Waiting for the after process \\
\hline Attribute 13 & Availability of changed parts \\
\hline Attribute 14 & Work help \\
\hline Attribute 15 & Work instructions in changeover \\
\hline Attribute 16 & Information flow related to changeover \\
\hline Ending setup & \multicolumn{2}{|l}{ Attribute 17} & Proper tools \\
\hline Attribute 18 & Quality issues \\
\hline Attribute 19 & Work help \\
\hline Attribute 21 & Information flow \\
\hline
\end{tabular}

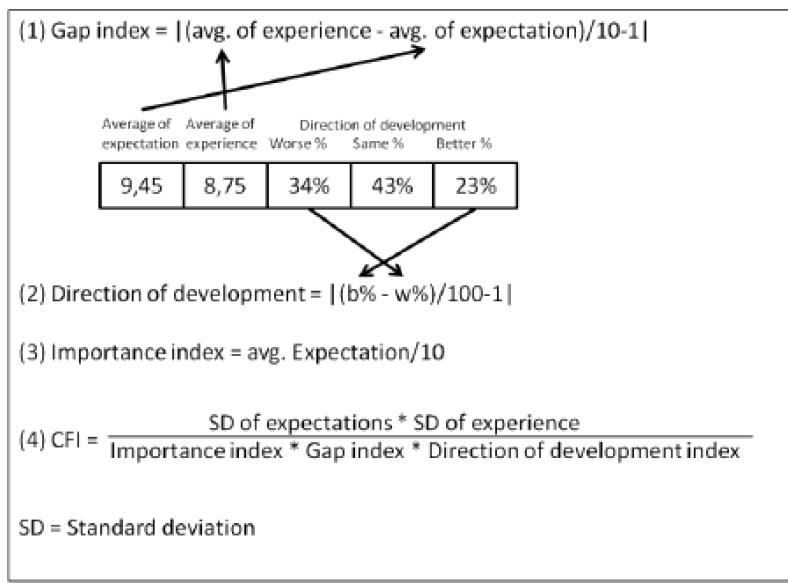

Fig. 2. Gap, direction of development, important, avg. of experience, avg. expectation, and CFI indexes [9].

Gathered information is analyzed by ten different index: average of expectations, average of experiences, importance index, performance index, Gap index, direction of development past, direction of 
development future, critical factor index (CFI), balanced critical factor index (BCFI) and scaled critical factor index (SCFI).

When gathered information is calculated by these indexes we can proceed to find critical attributes. Equations from 1 to 4 are detailed in Fig. 2. Gap analysis (1) is used to compare differences between customers expectations and experiences. With this basic tool, those attributes where the experiences were more insignificant than expectations, can be identified [10]. Direction of development is revealing the direction of each attributes development in past and future tenses. Important index and performance index are very close to each others. Both (Important index and performance index) are calculated by taking expectation or experiences number and then dividing it by the number ten. Most important indexes are the critical factor indexes (4). Critical factor indexes are explained in more detailed way in Fig. 3. These indexes are revealing attributes that can be named critical. Critical attribute is an attribute that will increase total productivity of a process. Adding more resources to critical attribute will make the existing process run more smoothly and efficiently. Critical index (CFI, BCFI, and SCFI) is also revealing attributes that are already in a good level of performance. If we add more resources into these attributes, we don't increase process overall efficiency. BCFI index is a basically same index as CFI but it has been weighted by performance index. SCFI index has been created to solve problems that are occurred when respondent sample is too narrow. For working properly, critical indexes need 3 or more respondents.

(5) $\mathrm{BCF}=\frac{\text { SD of expections } x \mathrm{SD} \text { of experience } \mathrm{x} \text { performance index }}{\text { Importance index } x \text { Gap index } x \text { direction of development index }}$

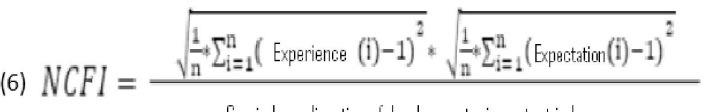
Gap index $x$ direction of development $x$ important index

(7) $S C F I=\frac{\text { NCFI }}{\sum(N C F I)}$

Fig. 3. BCFI, NCFI and SCFI index [11, 12].

\section{Research empirical part}

\section{SMED analysis}

SMED method was used to research same start, changeover, and ending setups as in the questionnaire method. Research was conducted as the theory insisted by three stages. All production process- es (product producing, 1 area packaging and 2 area packaging) were investigated. Totally amount of SMED research was 22 monitoring in spread department and 20 in quark department. Focus was in bottlenecks that were revealed during the study. Every monitoring produced a table were we can see how the investigated work phase was created. After creating table, like Table 2, we could accurately create another table where all the possible internal works could be moved to external work.

Table 2

SMED Table of 1 area packaging machine changeover in spread department.

\begin{tabular}{|c|c|c|c|}
\hline Work phase & Time & Internal & External \\
\hline Upper interleaf bowl out & 20 & & $\mathrm{x}$ \\
\hline Production ending & 40 & $\mathrm{x}$ & \\
\hline $\begin{array}{l}\text { Cases out from the conveyor } \\
\text { belt }\end{array}$ & 40 & $\mathrm{x}$ & \\
\hline Lids out of the magazine & 45 & $\mathrm{x}$ & \\
\hline Extra lids out of the machine & 105 & $\mathrm{x}$ & \\
\hline $\begin{array}{l}\text { Extra cases out of the ma- } \\
\text { chine }\end{array}$ & 55 & $\mathrm{x}$ & \\
\hline $\begin{array}{l}\text { Taking cases+interleaf out } \\
\text { and fech new ones }\end{array}$ & 125 & $\mathrm{x}$ & \\
\hline $\begin{array}{l}\text { Taking lids out and fech new } \\
\text { ones }\end{array}$ & 235 & $\mathrm{x}$ & \\
\hline Zeroing counter & 5 & $\mathrm{x}$ & \\
\hline $\begin{array}{l}\text { Loading setup }+ \text { change } \\
\text { packaking size }\end{array}$ & 15 & $\mathrm{x}$ & \\
\hline Stages 1 to 3 & 35 & $\mathrm{x}$ & \\
\hline Feching the part car & 45 & $\mathrm{x}$ & \\
\hline $\begin{array}{l}\text { Changing interlefs to lower } \\
\text { bowls }\end{array}$ & 100 & $\mathrm{x}$ & \\
\hline $\begin{array}{l}\text { Changing interlefs to upper } \\
\text { bowls }\end{array}$ & 35 & $\mathrm{x}$ & \\
\hline Change of lid grabers & 105 & $\mathrm{x}$ & \\
\hline Stages $5-7$ & 40 & $\mathrm{x}$ & \\
\hline Change of case jig & 70 & $\mathrm{x}$ & \\
\hline Stages $9-10$ & 30 & $\mathrm{x}$ & \\
\hline Change of case plate & 85 & $\mathrm{x}$ & \\
\hline OEE + product number & 40 & $\mathrm{x}$ & \\
\hline $\begin{array}{l}\text { Old packaking materils out } \\
\text { from the inside of machine }\end{array}$ & 50 & $\mathrm{x}$ & \\
\hline $\begin{array}{l}\text { Starting cases into the ma- } \\
\text { chine }\end{array}$ & 70 & $\mathrm{x}$ & \\
\hline Cases to the magazine & 295 & $\mathrm{x}$ & \\
\hline Lids to the magazine & 345 & $\mathrm{x}$ & \\
\hline Change of weight system & 85 & $\mathrm{x}$ & \\
\hline taking out the part car & 30 & $\mathrm{x}$ & \\
\hline Starting the production & 170 & $\mathrm{x}$ & \\
\hline $\begin{array}{l}\text { Work stage: Grunwald } 600 \mathrm{~g} \\
\text { was changed to } 400 \text { g. } 2 \text { per- } \\
\text { son did the job. Started 9:28 } \\
\text { Ended 9:57 } 29 \text { min }\end{array}$ & 2315 & 27 & 1 \\
\hline Internal time & $38 \min 5 \mathrm{~s}$ & & \\
\hline External time & $20 \mathrm{~s}$ & & \\
\hline Time total & $38 \min 25 \mathrm{~s}$ & & \\
\hline
\end{tabular}


In Table 3 we can see how process part could be improved. All the bolded work phases could be transformed into external phases. In this specific case internal time would be 25 minutes shorter then before. This would increase productive production time quite a lot. In Tables 4 and 5 we have monitored similar situation, but in quark department.

Table 3

SMED table of 1 area packaging machine changeover in spread department, corrected.

\begin{tabular}{|c|c|c|c|}
\hline Work phase & Time & Internal & External \\
\hline Upper interleaf bowl out & 20 & & $\mathrm{x}$ \\
\hline Production ending & 40 & $\mathrm{x}$ & \\
\hline $\begin{array}{l}\text { Cases out from the con- } \\
\text { veyor belt }\end{array}$ & 40 & & $\mathrm{x}$ \\
\hline Lids out of the magazine & 45 & & $\mathrm{x}$ \\
\hline $\begin{array}{l}\text { Extra lids out of the ma- } \\
\text { chine }\end{array}$ & 105 & & $\mathrm{x}$ \\
\hline $\begin{array}{l}\text { Extra cases out of the ma- } \\
\text { chine }\end{array}$ & 55 & & $\mathrm{x}$ \\
\hline $\begin{array}{l}\text { Taking cases+interleaf } \\
\text { out and fech new ones }\end{array}$ & 125 & & $\mathrm{x}$ \\
\hline $\begin{array}{l}\text { Taking lids out and fech } \\
\text { new ones }\end{array}$ & 235 & & $\mathrm{x}$ \\
\hline Zeroing counter & 5 & $\mathrm{x}$ & \\
\hline $\begin{array}{l}\text { Loading setup }+ \text { change } \\
\text { packaking size }\end{array}$ & 15 & $\mathrm{x}$ & \\
\hline Stages 1 to 3 & 35 & $\mathrm{x}$ & \\
\hline Feching the part car & 45 & & $\mathrm{x}$ \\
\hline $\begin{array}{l}\text { Changing interlefs to low- } \\
\text { er bowls }\end{array}$ & 100 & $\mathrm{x}$ & \\
\hline $\begin{array}{l}\text { Changing interlefs to up- } \\
\text { per bowls }\end{array}$ & 35 & & $\mathrm{x}$ \\
\hline Change of lid grabers & 105 & $\mathrm{x}$ & \\
\hline Stages $5-7$ & 40 & $\mathrm{x}$ & \\
\hline Change of case jig & 70 & & $\mathrm{x}$ \\
\hline Stages $9-10$ & 30 & $\mathrm{x}$ & \\
\hline Change of case plate & 85 & $\mathrm{x}$ & \\
\hline OEE + product number & 40 & $\mathrm{x}$ & \\
\hline $\begin{array}{l}\text { Old packaking materils } \\
\text { out from the inside of ma- } \\
\text { chine }\end{array}$ & 50 & & $\mathrm{x}$ \\
\hline $\begin{array}{l}\text { Starting cases into the ma- } \\
\text { chine }\end{array}$ & 70 & & $\mathrm{x}$ \\
\hline Cases to the magazine & 295 & & $\mathrm{x}$ \\
\hline Lids to the magazine & 345 & & $\mathrm{x}$ \\
\hline Change of weight system & 85 & $\mathrm{x}$ & \\
\hline taking out the part car & 30 & & $\mathrm{x}$ \\
\hline Starting the production & 170 & $\mathrm{x}$ & \\
\hline $\begin{array}{l}\text { Work stage: Grunwald } 600 \\
\text { g was changed to } 400 \text { g. } 2 \\
\text { person did the job. Start- } \\
\text { ed 9:28 Ended 9:57 } 29 \text { min }\end{array}$ & 2315 & 12 & 15 \\
\hline Internal time & $12 \min 30 \mathrm{~s}$ & & \\
\hline External time & $26 \min 5 \mathrm{~s}$ & & \\
\hline Time total & $38 \min 25 \mathrm{~s}$ & & \\
\hline Internal time less & $25 \min 35 \mathrm{~s}$ & & \\
\hline
\end{tabular}

Table 4

SMED table of 1 area packaging machine changeover in quark department.

\begin{tabular}{|c|c|c|c|}
\hline Work phase & Time & Internal & External \\
\hline $\begin{array}{l}\text { Fetching new packak- } \\
\text { ing materials + insert- } \\
\text { ing materials into ma- } \\
\text { chine }\end{array}$ & 180 & & $\mathrm{x}$ \\
\hline $\begin{array}{l}\text { End the product insert } \\
+ \text { end the production }\end{array}$ & 50 & $\mathrm{x}$ & \\
\hline $\begin{array}{ll}\text { Zeroing counter } \quad+ \\
\text { OEE }\end{array}$ & 35 & $\mathrm{x}$ & \\
\hline $\begin{array}{l}\text { Extra cases out of the } \\
\text { machine }\end{array}$ & 60 & $\mathrm{x}$ & \\
\hline $\begin{array}{l}\text { Starting cases into the } \\
\text { machine }\end{array}$ & 70 & $\mathrm{x}$ & \\
\hline Taking off dosing tubes & 105 & $\mathrm{x}$ & \\
\hline Dosing tubes pre-wash & 50 & $\mathrm{x}$ & \\
\hline $\begin{array}{l}\text { Activate cleanin-in- } \\
\text { progres }\end{array}$ & 75 & $\mathrm{x}$ & \\
\hline Changing pipe root & 15 & $\mathrm{x}$ & \\
\hline Machine CIP & 2400 & $\mathrm{x}$ & \\
\hline $\begin{array}{l}\text { Taking off interleafs } \\
\text { from the bowl }\end{array}$ & 225 & & $\mathrm{x}$ \\
\hline $\begin{array}{l}\text { Change the production } \\
\text { date marks }\end{array}$ & 39 & & $\mathrm{x}$ \\
\hline $\begin{array}{l}\text { Change of interleaf } \\
\text { takers }\end{array}$ & 140 & & $\mathrm{x}$ \\
\hline $\begin{array}{l}\text { Takeing old materials } \\
\text { away }\end{array}$ & 120 & & $\mathrm{x}$ \\
\hline CIP off & 92 & $\mathrm{x}$ & \\
\hline $\begin{array}{l}\text { Inserting the dosing } \\
\text { tubes }\end{array}$ & 180 & $\mathrm{x}$ & \\
\hline $\begin{array}{l}\text { Asking product pro- } \\
\text { ducers to start produc- } \\
\text { tion }\end{array}$ & 180 & $\mathrm{x}$ & \\
\hline $\begin{array}{l}\text { Filling up the product } \\
\text { bin }\end{array}$ & 95 & $\mathrm{x}$ & \\
\hline product circulate & 175 & $\mathrm{x}$ & \\
\hline $\begin{array}{l}\text { Cleaning the product } \\
\text { tubes }\end{array}$ & 60 & $\mathrm{x}$ & \\
\hline $\begin{array}{l}\text { Starting the produc- } \\
\text { tion }\end{array}$ & 420 & $\mathrm{x}$ & \\
\hline $\begin{array}{l}\text { Work phase: Grunwald } \\
\text { changeover 9.11.11. } 2 \\
\text { person did the job. } \\
\text { Started } 15: 45 \text { Ended } \\
16: 55\end{array}$ & 4766 & 16 & 5 \\
\hline Internal time & $1 \mathrm{~h} 7 \min 42 \mathrm{~s}$ & & \\
\hline External time & $11 \mathrm{~min} 44 \mathrm{~s}$ & & \\
\hline
\end{tabular}

In quark department all monitored SMED situations were a bit more difficult to transform. It was clear that in this department production efficiency improvement had already been in under the surveillance. There were only few things that could be improved and this was the situation in almost all the cases. Last step was to improve internal work phases as much as possible. 
Table 5

SMED table of 1 area packaging machine changeover in quark department, corrected.

\begin{tabular}{|c|c|c|c|}
\hline Work phase & Time & Internal & External \\
\hline $\begin{array}{l}\text { Fetching new packak- } \\
\text { ing materials + insert- } \\
\text { ing materials into ma- } \\
\text { chine }\end{array}$ & 180 & & $\mathrm{x}$ \\
\hline $\begin{array}{l}\text { End the product insert } \\
+ \text { end the production }\end{array}$ & 50 & $\mathrm{x}$ & \\
\hline $\begin{array}{l}\text { Zeroing counter } \quad+ \\
\text { OEE }\end{array}$ & 35 & & $\mathrm{x}$ \\
\hline $\begin{array}{l}\text { Extra cases out of the } \\
\text { machine }\end{array}$ & 60 & & $\mathrm{x}$ \\
\hline $\begin{array}{l}\text { Starting cases into the } \\
\text { machine }\end{array}$ & 70 & & $\mathrm{x}$ \\
\hline Taking off dosing tubes & 105 & $\mathrm{x}$ & \\
\hline Dosing tubes pre-wash & 50 & & $\mathrm{x}$ \\
\hline $\begin{array}{l}\text { Activate cleanin-in- } \\
\text { progres }\end{array}$ & 75 & $\mathrm{x}$ & \\
\hline Changing pipe root & 15 & $\mathrm{x}$ & \\
\hline Machine CIP & 2400 & $\mathrm{x}$ & \\
\hline $\begin{array}{l}\text { Taking off interleafs } \\
\text { from the bowl }\end{array}$ & 225 & & $\mathrm{x}$ \\
\hline $\begin{array}{l}\text { Change the production } \\
\text { date marks }\end{array}$ & 39 & & $\mathrm{x}$ \\
\hline $\begin{array}{l}\text { Change of interleaf } \\
\text { takers }\end{array}$ & 140 & & $\mathrm{x}$ \\
\hline $\begin{array}{l}\text { Takeing old materials } \\
\text { away }\end{array}$ & 120 & & $\mathrm{x}$ \\
\hline CIP off & 92 & $\mathrm{x}$ & \\
\hline $\begin{array}{l}\text { Inserting the dosing } \\
\text { tubes }\end{array}$ & 180 & $\mathrm{x}$ & \\
\hline $\begin{array}{l}\text { Asking product pro- } \\
\text { ducers to start produc- } \\
\text { tion }\end{array}$ & 180 & & $\mathrm{x}$ \\
\hline $\begin{array}{l}\text { Filling up the product } \\
\text { bin }\end{array}$ & 95 & $\mathrm{x}$ & \\
\hline product circulate & 175 & $\mathrm{x}$ & \\
\hline $\begin{array}{l}\text { Cleaning the product } \\
\text { tubes }\end{array}$ & 60 & $\mathrm{x}$ & \\
\hline $\begin{array}{l}\text { Starting the produc- } \\
\text { tion }\end{array}$ & 420 & $\mathrm{x}$ & \\
\hline $\begin{array}{l}\text { Work phase: Grunwald } \\
\text { changeover 9.11.11. } 2 \\
\text { person did the job. } \\
\text { Started 15:45 Ended } \\
16: 55\end{array}$ & 4766 & 11 & 10 \\
\hline Internal time & $1 \mathrm{~h} 1 \mathrm{~min} 7 \mathrm{~s}$ & & \\
\hline External time & $18 \min 19 \mathrm{~s}$ & & \\
\hline Time total & $1 \mathrm{~h} 19 \min 26 \mathrm{~s}$ & & \\
\hline Internal time less & $6 \min 35 \mathrm{~s}$ & & \\
\hline
\end{tabular}

Information was gathered by questionnaire which was specially designed to investigate these operational times. Four different personnel groups were selected to answer this questionnaire: product producers, 1 area packers, 2 area packers, and process supervisors.
When we are focusing on a specific problem like this we should investigate these production processes precisely. This is the main reason for these 21 attributes that are used in this research. All attributes are related to start, changeover, and ending setups. 30 people respond to the questionnaire, 17 from the spread production line and 13 from the quark line. Respond percent was 81 . Three or more responds were received per personnel group, but the process supervisors from the quark line gave only two responds. This is a bit problematic because in order to achieve dispersion, three or more replays should be collected. This is the reason why SCFI index was calculated in first place.

Tables 6 and 7 are showing preliminary results of spread and quark lines which are analyzed by indexes that are introduced in this research.

We can notice that all the attribute experience averages are smaller then the expectations in both production lines. Still the level of grades is in good stages at both lines. Standard deviation is considered to be high on some attributes, but if the SD of an attribute is high on expectations it will be lower in the experience category. Gap index is showing how experiences have lower numbers then the expectations. If the gap number is big then the gap between experience and expectation is wide. Small number in development index is indicating that the attribute has developed well.

Critical indexes can be found in the Tables 8 and 9. All factors have been analyzed by past and future development index. Indexes are formed from the numbers that have been calculated together from each personnel group.

CFI and BCFI index solutions should be monitored with a hint of skepticism, because there weren't enough answers to create acceptable level of confidence due to poor level of standard deviation. SCFI index proved to be the key index in this research. Critical factors that were found out by this index were attributes that matched with the problems and development targets of both production lines.

\section{Preliminary analysis for all (spread department)}

We can see that there are four major critical attributes. Attributes 6 and 21 are related to the communication between different personnel groups in start and ending setup. Attribute 9 (production schedule) is the clearest critical factor. Also attribute 18 (quality issues in ending works) is critical. Highest numbers were given to a tools that are needed in changeover and ending work. 
Table 6

Preliminary result for answers collected from spread department.

\begin{tabular}{l|c|c|c|c|c|c|c}
\hline & $\begin{array}{c}\text { Average } \\
\text { of expectation }\end{array}$ & $\begin{array}{c}\text { SD } \\
\text { Expectation }\end{array}$ & $\begin{array}{c}\text { Average } \\
\text { of experience }\end{array}$ & $\begin{array}{c}\text { SD } \\
\text { Experience }\end{array}$ & $\begin{array}{c}\text { Gap } \\
\text { index }\end{array}$ & $\begin{array}{c}\text { Development } \\
\text { index past }\end{array}$ & $\begin{array}{c}\text { Development } \\
\text { index future }\end{array}$ \\
\hline Attribute 1 & 9.21 & 0.41 & 8.17 & 0.78 & 1.13 & 0.77 & 0.77 \\
\hline Attribute 2 & 9.19 & 0.65 & 8.34 & 0.67 & 1.11 & $\mathbf{0 . 4 7}$ & 0.77 \\
\hline Attribute 3 & 9.19 & 0.59 & 7.74 & 0.62 & 1.18 & 1.00 & $\mathbf{0 . 4 7}$ \\
\hline Attribute 4 & 8.11 & 1.42 & 7.54 & $\mathbf{1 . 4 6}$ & 1.07 & 1.00 & 1.00 \\
\hline Attribute 5 & 7.46 & 1.36 & 6.54 & 0.86 & 1.12 & 1.30 & 0.77 \\
\hline Attribute 6 & 8.71 & 0.76 & 6.66 & 1.09 & $\mathbf{1 . 2 6}$ & 1.23 & 0.85 \\
\hline Attribute 7 & $\mathbf{9 . 3 0}$ & 0.47 & $\mathbf{8 . 6 5}$ & 0.30 & 1.08 & 0.77 & 0.77 \\
\hline Attribute 8 & 9.05 & 0.79 & $\mathbf{8 . 5 8}$ & 0.42 & 1.06 & $\mathbf{0 . 4 0}$ & 0.77 \\
\hline Attribute 9 & $\mathbf{9 . 4 0}$ & 0.48 & 6.53 & 0.91 & $\mathbf{1 . 3 6}$ & 1.08 & 0.92 \\
\hline Attribute 10 & $\mathbf{9 . 3 0}$ & 0.59 & 8.05 & 0.27 & 1.16 & 0.92 & 0.62 \\
\hline Attribute 11 & 8.02 & 1.59 & 7.83 & 0.59 & 1.02 & 0.85 & 0.62 \\
\hline Attribute 12 & 8.09 & $\mathbf{1 . 6 5}$ & 7.27 & 0.55 & 1.10 & 0.92 & $\mathbf{0 . 5 5}$ \\
\hline Attribute 13 & 9.19 & 0.91 & 8.54 & 0.58 & 1.08 & 0.62 & 0.92 \\
\hline Attribute 14 & 8.24 & 1.09 & 7.48 & $\mathbf{1 . 4 4}$ & 1.10 & 1.08 & 0.92 \\
\hline Attribute 15 & 9.16 & 0.82 & 8.00 & 1.06 & 1.15 & 0.77 & 0.62 \\
\hline Attribute 16 & 8.84 & 1.09 & 6.78 & 1.28 & $\mathbf{1 . 2 6}$ & 1.23 & 0.62 \\
\hline Attribute 17 & 8.90 & 0.97 & 8.52 & 0.39 & 1.05 & 0.70 & 0.70 \\
\hline Attribute 18 & 9.06 & 0.93 & 8.11 & 0.37 & 1.12 & 1.00 & 0.77 \\
\hline Attribute 19 & 8.11 & 1.05 & 7.58 & 1.42 & 1.07 & 1.08 & 1.08 \\
\hline Attribute 20 & 7.88 & $\mathbf{1 . 6 4}$ & 7.11 & 0.98 & 1.10 & 1.00 & 0.77 \\
\hline Attribute 21 & 8.75 & 1.36 & 7.05 & 1.35 & 1.21 & 1.30 & 0.77 \\
\hline
\end{tabular}

Table 7

Preliminary result for answers collected from quark department.

\begin{tabular}{l|c|c|c|c|c|c|c}
\hline & $\begin{array}{c}\text { Average } \\
\text { of expectation }\end{array}$ & $\begin{array}{c}\text { SD } \\
\text { Expectation }\end{array}$ & $\begin{array}{c}\text { Average } \\
\text { of experience }\end{array}$ & $\begin{array}{c}\text { SD } \\
\text { Experience }\end{array}$ & $\begin{array}{c}\text { Gap } \\
\text { index }\end{array}$ & $\begin{array}{c}\text { Development } \\
\text { index past }\end{array}$ & $\begin{array}{c}\text { Development } \\
\text { index future }\end{array}$ \\
\hline Attribute 1 & 8.88 & 0.55 & 8.24 & 0.48 & 1.08 & $\mathbf{0 . 6 7}$ & 0.67 \\
\hline Attribute 2 & 8.83 & 1.38 & 7.98 & $\mathbf{1 . 6 2}$ & 1.11 & $\mathbf{0 . 6 7}$ & $\mathbf{0 . 3 3}$ \\
\hline Attribute 3 & $\mathbf{9 . 4 0}$ & 0.43 & 8.06 & 0.90 & 1.17 & $\mathbf{0 . 6 7}$ & 0.67 \\
\hline Attribute 4 & 8.94 & 0.25 & 6.96 & 0.51 & $\mathbf{1 . 2 5}$ & 1.00 & 0.67 \\
\hline Attribute 5 & 9.11 & 0.31 & 7.46 & 0.98 & 1.21 & 0.75 & 0.67 \\
\hline Attribute 6 & 8.08 & $\mathbf{2 . 1 0}$ & 6.67 & 1.30 & 1.18 & 1.00 & 1.00 \\
\hline Attribute 7 & 9.15 & 0.23 & 8.15 & 0.19 & 1.13 & $\mathbf{0 . 6 7}$ & 1.00 \\
\hline Attribute 8 & 9.15 & 0.23 & 8.20 & 0.18 & 1.12 & $\mathbf{0 . 4 2}$ & 0.67 \\
\hline Attribute 9 & 9.20 & 0.40 & 7.24 & 1.24 & $\mathbf{1 . 2 5}$ & 1.00 & $\mathbf{0 . 3 3}$ \\
\hline Attribute 10 & $\mathbf{9 . 5 3}$ & 0.25 & 8.07 & 0.30 & 1.18 & $\mathbf{0 . 6 7}$ & 0.67 \\
\hline Attribute 11 & 7.58 & $\mathbf{1 . 7 5}$ & 6.87 & 0.67 & 1.09 & 1.08 & $\mathbf{0 . 3 3}$ \\
\hline Attribute 12 & 8.50 & 0.48 & 7.55 & 0.48 & 1.12 & 0.92 & $\mathbf{0 . 3 3}$ \\
\hline Attribute 13 & 8.52 & 1.41 & 7.59 & 0.97 & 1.12 & 1.00 & 0.67 \\
\hline Attribute 14 & 8.85 & 1.20 & 6.89 & 0.70 & $\mathbf{1 . 2 5}$ & 1.00 & 0.67 \\
\hline Attribute 15 & 9.35 & 0.10 & 8.29 & 1.03 & 1.13 & 0.75 & 0.67 \\
\hline Attribute 16 & 8.60 & $\mathbf{1 . 7 5}$ & 6.99 & $\mathbf{1 . 6 7}$ & 1.20 & 1.08 & 0.67 \\
\hline Attribute 17 & 9.10 & 0.43 & $\mathbf{8 . 4 7}$ & 0.47 & 1.08 & 0.75 & 0.67 \\
\hline Attribute 18 & 9.25 & 0.15 & $\mathbf{8 . 5 5}$ & 0.56 & 1.09 & 0.83 & 1.00 \\
\hline Attribute 19 & 8.79 & 0.77 & 6.73 & 1.07 & $\mathbf{1 . 2 6}$ & 1.00 & 1.00 \\
\hline Attribute 20 & 8.69 & 0.70 & 7.75 & 0.51 & 1.12 & 0.83 & 0.67 \\
\hline Attribute 21 & 8.48 & 1.67 & 6.76 & 1.61 & 1.21 & 0.92 & $\mathbf{0 . 3 3}$ \\
\hline
\end{tabular}


Management and Production Engineering Review

Table 8

Preliminary result for critical indexes (CFI and BCFI) from the spread and quark department.

\begin{tabular}{l|c|c|c|c|c|c|c|c}
\hline & $\begin{array}{c}\text { CFI past } \\
\text { spread }\end{array}$ & $\begin{array}{c}\text { CFI past } \\
\text { quark }\end{array}$ & $\begin{array}{c}\text { CFI future } \\
\text { spread }\end{array}$ & $\begin{array}{c}\text { CFI future } \\
\text { quark }\end{array}$ & $\begin{array}{c}\text { BCFI past } \\
\text { spread }\end{array}$ & $\begin{array}{c}\text { BCFI past } \\
\text { quark }\end{array}$ & $\begin{array}{c}\text { BCFI future } \\
\text { spread }\end{array}$ & $\begin{array}{c}\text { BCFI future } \\
\text { quark }\end{array}$ \\
\hline Attribute 1 & $\mathbf{0 . 0 1 4}$ & 0.010 & $\mathbf{0 . 0 1 0}$ & 0.008 & $\mathbf{0 . 0 1 5}$ & 0.012 & $\mathbf{0 . 0 1 2}$ & 0.010 \\
\hline Attribute 2 & 0.132 & 0.165 & 0.015 & 0.079 & 0.153 & 0.165 & 0.019 & 0.082 \\
\hline Attribute 3 & 0.036 & 0.017 & 0.103 & 0.051 & 0.036 & 0.019 & 0.114 & 0.054 \\
\hline Attribute 4 & 0.084 & 0.076 & 0.056 & 0.029 & 0.080 & 0.074 & 0.058 & 0.031 \\
\hline Attribute 5 & 0.062 & $\mathbf{0 . 0 0 8}$ & 0.092 & $\mathbf{0 . 0 0 7}$ & 0.046 & $\mathbf{0 . 0 0 8}$ & 0.072 & $\mathbf{0 . 0 0 8}$ \\
\hline Attribute 6 & 0.030 & 0.090 & 0.034 & 0.130 & 0.024 & 0.070 & 0.028 & 0.103 \\
\hline Attribute 7 & $\mathbf{0 . 0 1 7}$ & 0.022 & $\mathbf{0 . 0 1 2}$ & 0.012 & 0.020 & 0.026 & 0.016 & 0.014 \\
\hline Attribute 8 & 0.087 & 0.046 & 0.024 & 0.014 & 0.102 & 0.057 & 0.031 & 0.016 \\
\hline Attribute 9 & 0.024 & 0.038 & 0.016 & 0.035 & 0.023 & 0.039 & $\mathbf{0 . 0 1 2}$ & 0.036 \\
\hline Attribute 10 & 0.023 & 0.020 & 0.020 & 0.018 & 0.024 & 0.020 & 0.023 & 0.020 \\
\hline Attribute 11 & 0.075 & 0.100 & 0.056 & 0.118 & 0.090 & 0.095 & 0.074 & 0.116 \\
\hline Attribute 12 & 0.034 & $\mathbf{0 . 0 0 7}$ & 0.071 & 0.010 & 0.030 & $\mathbf{0 . 0 0 8}$ & 0.069 & 0.011 \\
\hline Attribute 13 & 0.033 & 0.067 & 0.022 & 0.094 & 0.039 & 0.079 & 0.029 & 0.113 \\
\hline Attribute 14 & 0.059 & 0.126 & 0.056 & 0.106 & 0.054 & 0.122 & 0.055 & 0.105 \\
\hline Attribute 15 & 0.054 & 0.018 & 0.054 & 0.015 & 0.053 & 0.021 & 0.056 & 0.018 \\
\hline Attribute 16 & 0.021 & 0.071 & 0.054 & 0.137 & $\mathbf{0 . 0 1 5}$ & 0.062 & 0.041 & 0.123 \\
\hline Attribute 17 & 0.029 & $\mathbf{0 . 0 0 6}$ & 0.046 & $\mathbf{0 . 0 0 5}$ & 0.033 & $\mathbf{0 . 0 0 7}$ & 0.061 & $\mathbf{0 . 0 0 7}$ \\
\hline Attribute 18 & 0.028 & 0.011 & 0.025 & 0.014 & 0.030 & 0.014 & 0.032 & 0.017 \\
\hline Attribute 19 & 0.054 & 0.093 & 0.049 & 0.076 & 0.050 & 0.086 & 0.047 & 0.072 \\
\hline Attribute 20 & 0.062 & 0.033 & 0.121 & 0.040 & 0.049 & 0.035 & 0.100 & 0.044 \\
\hline Attribute 21 & 0.044 & 0.074 & 0.065 & 0.141 & 0.032 & 0.059 & 0.051 & 0.114 \\
\hline
\end{tabular}

Table 9

Preliminary result for SCFI index from the spread line, all personnel groups.

\begin{tabular}{l|c|c|c|c|c|c|c|c}
\hline \multirow{2}{*}{ SCFI } & \multicolumn{2}{|c|}{ product producers } & \multicolumn{2}{c|}{1 area packers } & \multicolumn{2}{c|}{2 area packers } & \multicolumn{2}{c}{ process supervisors } \\
\cline { 2 - 9 } & past & future & past & future & past & future & past & future \\
\hline Attribute 1 & 0.06572 & 0.03997 & 0.04240 & 0.04028 & 0.05150 & 0.03646 & 0.02604 & 0.03930 \\
\hline Attribute 2 & 0.32252 & 0.04830 & 0.05122 & 0.03741 & 0.08745 & 0.03530 & 0.04947 & 0.04257 \\
\hline Attribute 3 & 0.05822 & 0.03541 & 0.02979 & 0.24814 & 0.02643 & 0.04975 & 0.02533 & 0.15525 \\
\hline Attribute 4 & 0.04104 & 0.03366 & 0.05023 & 0.02566 & 0.04150 & 0.06006 & $\mathbf{0 . 0 1 5 9 9}$ & 0.01790 \\
\hline Attribute 5 & $\mathbf{0 . 0 1 9 7 9}$ & 0.05612 & 0.03229 & 0.03776 & 0.02443 & $\mathbf{0 . 0 3 2 1 6}$ & 0.01962 & 0.02414 \\
\hline Attribute 6 & 0.02024 & 0.04014 & $\mathbf{0 . 0 1 9 0 4}$ & $\mathbf{0 . 0 1 5 5 8}$ & $\mathbf{0 . 0 2 1 2 4}$ & 0.07012 & 0.02342 & $\mathbf{0 . 0 1 4 1 0}$ \\
\hline Attribute 7 & 0.06891 & 0.04191 & 0.05947 & 0.04343 & 0.03914 & 0.03962 & 0.02923 & 0.04411 \\
\hline Attribute 8 & 0.07198 & 0.06259 & 0.08503 & 0.03038 & 0.10597 & 0.04278 & 0.20816 & 0.04411 \\
\hline Attribute 9 & $\mathbf{0 . 0 1 3 9 8}$ & $\mathbf{0 . 0 2 1 3 2}$ & $\mathbf{0 . 0 1 5 9 3}$ & $\mathbf{0 . 0 1 5 4 8}$ & $\mathbf{0 . 0 1 8 6 0}$ & 0.04722 & 0.19403 & $\mathbf{0 . 0 1 6 4 0}$ \\
\hline Attribute 10 & 0.02113 & 0.05992 & 0.06880 & 0.03514 & 0.03438 & 0.04975 & 0.02533 & 0.03823 \\
\hline Attribute 11 & 0.02884 & 0.06288 & 0.11695 & 0.05974 & 0.03673 & 0.05316 & 0.02925 & 0.04414 \\
\hline Attribute 12 & 0.03503 & 0.05342 & 0.04286 & 0.07140 & 0.03411 & 0.08657 & 0.03120 & 0.02685 \\
\hline Attribute 13 & 0.04202 & 0.04481 & 0.05919 & 0.04323 & 0.09089 & 0.03669 & 0.05169 & 0.01774 \\
\hline Attribute 14 & 0.02774 & 0.04231 & 0.02821 & 0.02307 & 0.05760 & 0.05830 & 0.02090 & 0.01799 \\
\hline Attribute 15 & 0.02144 & 0.06080 & 0.05533 & 0.04957 & 0.05596 & 0.05664 & 0.04970 & 0.02439 \\
\hline Attribute 16 & 0.02154 & 0.06109 & 0.02217 & 0.04546 & 0.02419 & 0.03501 & $\mathbf{0 . 0 1 5 4 8}$ & 0.01905 \\
\hline Attribute 17 & 0.02994 & 0.04565 & 0.05381 & 0.03930 & 0.11013 & 0.04445 & 0.05539 & 0.19358 \\
\hline Attribute 18 & $\mathbf{0 . 0 1 7 0 9}$ & $\mathbf{0 . 0 3 2 0 8}$ & 0.07978 & 0.02850 & 0.02681 & 0.05047 & 0.04753 & 0.16612 \\
\hline Attribute 19 & 0.02283 & 0.03482 & 0.02821 & 0.02307 & 0.05760 & 0.04077 & 0.03376 & 0.02032 \\
\hline Attribute 20 & 0.02896 & 0.06315 & 0.03636 & 0.06057 & 0.03382 & $\mathbf{0 . 0 3 4 2 3}$ & 0.03101 & 0.01866 \\
\hline Attribute 21 & 0.02104 & 0.05966 & 0.02293 & 0.02681 & 0.02151 & 0.04049 & $\mathbf{0 . 0 1 7 4 9}$ & $\mathbf{0 . 0 1 5 0 6}$ \\
\hline
\end{tabular}




\section{Preliminary analysis, product producers (spread department)}

Critical factors are attributes 5,8 , and 18 when measured in past. Waiting for other parts of the process in start works (5), production schedule (9), and quality issues in ending works (18) should be improved if we wanted to increase our productivity from the product producers point of view. When estimated these attributes with future aspect same critical factors emerge. Only other team waiting is turned into the green zone. Attributes 2, 8, 11, and 20 is considered to be in a good level or level that should be investigated more precisely.

\section{Preliminary analysis, 1 area packers (spread department)}

1 area packers are considering production schedule (9) and information flow in start work (6) to be critical factors. Both critical attributes are also critical if we look SCFI index by the view of future tense. Best attributes are proper tools (8) and previous process waiting in changeovers (11). In the future best attributes will be quality issues in start setup (3) and previous process waiting in the changeovers (12).

\section{Preliminary analysis, 2 area packers (spread department)}

2 area packers feel that critical factor should be almost same as what 1 area packers have chosen. In the past attributes 6 and 9 . In the future tense critical factors are different. Other teams waiting in start (5) and ending works (20) is considered to be critical. Highest score was given to attributes that are related to tools and parts that are changed in changeover setups $(8,13$, and 17). Information flow in start setup (6) and waiting for the after process in changeover setup (12) is voted for the best candidates in future. We should notice that the critical attribute, information flow in start setups, will change its state in the future tense to be almost best attribute. This is indicating that people are hoping a big change to this attribute.

\section{Preliminary analysis, process supervisors (spread department)}

Process supervisors have chosen few attributes to be critical factors: information flow in changeover (16), ending setups (21), and also work help in start setups (4). Attributes that will be critical in future are information flow in ending (21) and start setups (6), and also production schedule (9). Production schedule is very interesting attribute, because it is one of the best attributes in the past, but it will drop to critical in the future. Proper tools in changeover (8) have also received high qualification. Ending setup tools (17) have received major numbers at the future tense. Other attribute that had high value were quality issues at ending setups (18).

\section{Preliminary analysis for all (quark department)}

SCFI index is indicating that there are three critical attributes in the quark department. Availability of material/raw materials $(1,7)$ are attributes that are critical in future. Also work help in ending setups will be in critical phase. In past, information flow in changeovers and quality issues in start, are Considered to be critical attributes. Next we are analyzing different personal groups. Data can be found from the Table 10.

\section{Preliminary analysis, product producers (quark department)}

Product producers have chosen product schedule (9) and information flow in start setup (6) to be critical. In future critical attributes will be waiting for the previous process (11) and proper tools (8) in changeover. Product producers are feeling that needed tools in changeover are in best shape at the past but they will be critical in future. Reason for this could be found from the level that tools have already achieved. High qualification is causing sinking in the future. Other attributes that rose up were tools in start setup (2), quality issues in start, and changeover setups $(3,10)$.

\section{Preliminary analysis, 1 area packers (quark department)}

1 area packers have chosen only one attribute to be critical. Work help $(4,14$, and 19) in every part of start, changeover and ending setups. This attribute is critical in both tenses past and future. Clear message is indicating that more help is needed in the 1 area. Production schedule (9) will be also critical in future. In past, good attributes are other teams waiting in start setup (5) and quality issues in ending setup (18). In future critical factors will be quality issues (3) and proper tools (2) in start setup. 
Table 10

Preliminary result for SCFI index from the quark line, all personnel groups.

\begin{tabular}{l|c|c|c|c|c|c|c|c}
\hline \multirow{2}{*}{ SCFI } & \multicolumn{2}{|c|}{ product producers } & \multicolumn{2}{c|}{1 area packers } & \multicolumn{2}{c|}{2 area packers } & \multicolumn{2}{c}{ process supervisors } \\
\cline { 2 - 9 } & past & future & past & future & past & future & past & future \\
\hline Attribute 1 & 0.06041 & 0.03403 & 0.05312 & 0.03441 & 0.03170 & 0.06525 & 0.08980 & 0.04911 \\
\hline Attribute 2 & 0.06370 & 0.03589 & 0.05032 & 0.04660 & 0.04920 & 0.03292 & 0.04820 & 0.08107 \\
\hline Attribute 3 & 0.05926 & 0.08371 & 0.04172 & 0.27524 & 0.04584 & 0.03068 & 0.04820 & 0.04623 \\
\hline Attribute 4 & 0.04455 & 0.05131 & $\mathbf{0 . 0 1 9 9 8}$ & $\mathbf{0 . 0 1 5 9 4}$ & 0.15500 & 0.04479 & $\mathbf{0 . 0 1 9 7 6}$ & 0.03525 \\
\hline Attribute 5 & 0.03599 & 0.06270 & 0.13751 & 0.03552 & $\mathbf{0 . 0 1 6 5 3}$ & $\mathbf{0 . 0 1 9 4 0}$ & 0.03530 & 0.03386 \\
\hline Attribute 6 & $\mathbf{0 . 0 3 4 0 9}$ & 0.06885 & 0.05432 & 0.02461 & $\mathbf{0 . 0 1 5 2 9}$ & 0.03338 & 0.03284 & 0.03150 \\
\hline Attribute 7 & 0.06330 & 0.03566 & 0.05312 & 0.03441 & 0.02665 & 0.03128 & 0.07792 & $\mathbf{0 . 0 2 9 8 0}$ \\
\hline Attribute 8 & 0.10518 & $\mathbf{0 . 0 3 3 7 9}$ & 0.04764 & 0.07739 & 0.23103 & 0.03807 & 0.07792 & 0.04261 \\
\hline Attribute 9 & $\mathbf{0 . 0 1 9 8 6}$ & 0.03662 & 0.02816 & $\mathbf{0 . 0 2 2 4 5}$ & 0.03229 & 0.03789 & 0.08453 & 0.08107 \\
\hline Attribute 10 & 0.04481 & 0.09051 & 0.05521 & 0.06272 & 0.04145 & $\mathbf{0 . 0 2 7 7 3}$ & 0.04872 & 0.04673 \\
\hline Attribute 11 & 0.05234 & 0.06028 & 0.02995 & 0.03607 & 0.02352 & 0.03946 & 0.03149 & 0.07572 \\
\hline Attribute 12 & 0.04087 & $\mathbf{0 . 0 3 2 9 2}$ & 0.05573 & 0.05162 & 0.02661 & 0.05477 & 0.03149 & 0.07572 \\
\hline Attribute 13 & 0.03627 & 0.03753 & 0.03425 & 0.04125 & 0.03781 & 0.07782 & 0.04820 & 0.04623 \\
\hline Attribute 14 & 0.04254 & 0.04899 & $\mathbf{0 . 0 2 2 6 9}$ & $\mathbf{0 . 0 1 4 7 0}$ & 0.05100 & 0.05985 & $\mathbf{0 . 0 1 6 9 3}$ & 0.03020 \\
\hline Attribute 15 & 0.04602 & 0.04512 & 0.03833 & 0.03230 & 0.02827 & 0.05818 & 0.08544 & 0.04673 \\
\hline Attribute 16 & 0.03798 & 0.04374 & 0.02642 & 0.03182 & $\mathbf{0 . 0 1 9 0 8}$ & 0.05614 & 0.03061 & 0.04197 \\
\hline Attribute 17 & 0.04225 & 0.04866 & 0.05528 & 0.03581 & 0.05792 & 0.06797 & 0.04820 & 0.04623 \\
\hline Attribute 18 & 0.04427 & 0.03566 & 0.08237 & 0.05335 & 0.02183 & 0.06424 & 0.04502 & 0.03020 \\
\hline Attribute 19 & 0.04673 & 0.03764 & $\mathbf{0 . 0 2 1 9 9}$ & $\mathbf{0 . 0 1 4 2 4}$ & 0.04268 & 0.05009 & $\mathbf{0 . 0 1 6 9 3}$ & $\mathbf{0 . 0 2 1 1 2}$ \\
\hline Attribute 20 & 0.04397 & 0.03542 & 0.05225 & 0.03385 & 0.02952 & 0.06075 & 0.04158 & 0.03987 \\
\hline Attribute 21 & 0.03560 & 0.04100 & 0.03964 & 0.02568 & $\mathbf{0 . 0 1 6 7 7}$ & 0.04934 & 0.04091 & 0.06880 \\
\hline
\end{tabular}

\section{Preliminary analysis, 2 area packers (quark department)}

Information flow $(6,16$, and 21$)$ is named to be critical attribute in every part of the process. In future 2 area thinks that all the information problems will be diminished to non-critical attributes. In future other teams waiting in start setup (5) and quality issues in changeover (10) has chosen to be critical. Work help in start setup (4) and proper tools in changeover (8) are in good side of the scale in past. In future parts that are needed in changeover (13) and proper tools in ending setup (17) will be in good hands.

\section{Preliminary analysis, process supervisors (quark department)}

Work help $(4,14,19)$ is critical in start, changeover and ending setups. Work help is also critical in future, but only in ending works. Other attribute that is lacking resources is availability of material/raw material in changeover (7). In the good side, there are availability of material/raw material in start setup (1) and work instructions in changeover (15). In future, there will be proper tools in start setup (2) and production schedule (9) that are in good stage.

\section{Conclusions}

In the long run all these changes should be effecting to production efficiency. Effectiveness can be monitored and measured by OEE. OEE should be increased from the availability part. Results, which were received from questionnaire method, were tested with semi-strong market test. In this test all results were verified with the help of operating personnel. Critical attributes were founded. Difference between CFI, BCFI, and SCFI indexes can be explained with the standard deviation and different weightings in the answers. SCFI index gave best results when critical factors were presented to the personnel. Also SMED method was giving results that specific attributes should be improved. And these attributes were the same critical factors what we got from the questionnaire analyze. Research is indicating that in order to get valid results, both methods should be used simultaneously.

Reliability of the research results can be stated to be correct. All information was gathered from the process with researchers own experience included. Monitoring the process was very crucial to the research. For the further development of these methods, information could be gathered for a longer time. This would improve results, because with more start, 
changeover, and end setups monitored material could be trusted more and then the personnels way of doing work phases could be monitored better. This would lead to findings for the best working habits.

\section{References}

[1] Cakmakci M., Process improvement: performance analysis of the setup time reduction-SMED in the automobile industry, International Journal of Advanced Manufacturing Technology, 41, 1/2, 168179, May 2009.

[2] Bhat K.S., Total Quality Management, Mumbai, IND, Global Media, p. 548, 2010.

[3] Wilson L., How to Implement Lean Manufacturing, New York, McGraw-Hill Professional Publishing, p. 69, 2009.

[4] Shingo S., A Study of the Toyota Production System, Portland, USA, Productivity Press, Inc., p. 43, 1989.

[5] Basu R., Implementing Quality: A Practical Guid to Tools and Techniques: Enabling the Power of Operational Excellence, 1, Ed. UK, Cengage Learning EMEA, p. 103, 2004.

[6] Haeckel S.H., Adaptive Enterprise, Creating and Leading Sense-and Respond Organisations, Boston, USA, Harvard Business School Press, pp. 2-4, 1999.
[7] Bradley S.P., Nolan R.L., Sense 63 respond: capturing value in the network era, Boston, USA, Harvard Business Press, p. 4, 1998.

[8] The 2nd International Conference on Logistics \& Transport, LOADO'2003, 10-12 September'2003 (High Tatras, Slovak Republik), Takala J., Rautiainen M., Measuring Customer Satisfaction and Increasing it by Choosing the Right Development Subjects, 2003.

[9] Nadler D., Takala J., The Development of the Critical Factor Index Method, University of Vaasa, Faculty of Technology, Department of Industrial Management, 2010.

[10] Ranta J.-M., Takala J., A Holistic method for finding out critical features of industry maintenance services, Int. J. Services and Standards, 3, 3, 312-325, 2007.

[11] The $12^{\text {th }}$ Management International Conference, MIC'2011, Sustainable Economy, November 22-27, 2011, Portoroz, Slovenia, Takala J., Leppiniemi Jari, Improving the Quality of Internal Processes by Sense and Respond Methods, p. 10, 2011.

[12] Takala J., Rymaszewska A., Koskinen J., Shi Z., Chen Y., The Implementation of the Balanced Critical Factor Index Methodology in the Strategy Redevelopment Process, International Journal Management and Production Engineering Review (MPER), 4, 1, 2012. 